\title{
The Effect of Traditional Gold Mining toward the Socio-Economic and Environmental Aspect in Sepauk District Sintang Regency
}

\author{
Depy Anggraini ${ }^{1}$, Soemarno ${ }^{2}$, Harsuko Riniwati ${ }^{3}$ \\ ${ }^{1}$ Graduate School of Environmental Resource Management and Development, Brawijaya University, Malang, Indonesia \\ ${ }^{2}$ Soil Department, Faculty of Agriculture, Brawijaya University, Malang, Indonesia \\ ${ }^{3}$ Department of Water Resources Management, Faculty of Fisheries and Marine Sciences, Brawijaya University
}

\begin{abstract}
The gold mining in Sepauk District in the watershed and the mainland causes problems from the economic, social, and environmental standpoint. The purpose of this study is to analyze the social, economic, and environmental conditions in Sepauk District of Sintang Regency and the impact of the traditional gold mining on the social, economic, and environmental aspects. This study uses a descriptive qualitative model where researchers collect data through observations, interviews, and documentation. The social aspects of education have increased considerably; health is still very limited with the lack of health facilities and medical personnel; age and sex, no children and women employed, average working age for work; tribe and religion is not a problem to work as a miner. Economic aspect in the form of livelihood change, formerly majority farming and now become miner and income enough increase and its environmental aspect is caused by road damage, river water pollution, land damage and noise. The traditional gold mining activities have had a positive impact such as improving the welfare of the people and reducing unemployment; yet, it also brings negative impact, such as health problems, road damage, river pollution, land damage, noise pollution, and land conflicts. Thus, it is recommended that the government guide and supervise the community in conducting the mining activities.
\end{abstract}

Keywords: Economy, Environment, Gold mining, Social

\section{INTRODUCTION}

The gold mining in Sepauk District in the watershed and the mainland causes problems from the economic, social, and environmental standpoint. Problems from the social aspect of the community in Sepauk District experienced a slight shift from livelihoods change, formerly working as farmers now shifting professions as miners. The problem with the economic aspect is that there are not a few people who depend on their income in this gold mining, because it becomes an additional source of income for the mining community. Then on the environmental aspect, it is unfortunate that gold mining is done without permission so that people do not think about the impact of environmental damage caused.

[1] According to Kompas (2017) data, about $70 \%$ of the environmental damage in Indonesia is caused by mining operations. This mining industry easily outsmart and override various rules against its interests, including the Law Number 32 of 2009 on the Management and

Corresponding author

Depy Anggraini

Email : depy.anggraini@gmail.com

Address : Graduate School of Environmental Resource Management and Development, University of Brawijaya, Malang, Indonesia
Protection of the Environment and the Law Number 4 of 2009 on Mineral and Coal Mining. [2] According to Edi Farlan et al. (2016: 335), mining has changed the social and economic activities of the community, especially on population movement, employment conflict, livelihood transition, and community income. [3] According to Kukuh Prasetyo et al. (2017: 66), traditional mining brings negative impacts on the environment, especially on the quality of waterthe wells and rivers are polluted, as they are located near the mining sites.

Based on this background, the purpose of this study is to analyze the social, economic, and environmental conditions and the impact of the traditional gold mining on the social, economic, and environmental aspects in Sepauk District of Sintang Regency.

\section{RESEARCH METHOD}

The study uses a descriptive qualitative approach, producing data in the form of speech of the research informants telling the facts in the field.

Data analysis in this study uses the procedure proposed by Miles, Huberman, and Saldana (2014: 31-33) of three activities simultaneously, i.e. data condensation, data display, and conclusion drawing or verifications. 
[1]. According to Edi Farlan (2016) indicator on the social aspect of population and livelihood, Kustiana, et al (2016), health indocators and Alfonso, et al (2014), indicators of age, length of stay and education. Edi Farlan (2016), indicator of employment, community income. Fadly, et al (2015), indicator of work, income increase, income increase. Kukuh Prasetyo (2017), an indicator of water pollution. Astiti, et al (2014), an indicator of heavy metal (mercury) pollution. Fadly, et al (2015), an indicator of sound pollution, air pollution, road damage. The focus of this study is [2]. social conditions, whose indicators are education, health, age and sex, and ethnicity and religion; economic conditions, whose indicators are livelihood, income, and employment; and environmental aspects, whose indicators are road damage, river pollution, forest destruction, and noise pollution. [3]. The positive and negative impacts of mining activities are viewed from the social, economic, and environmental aspects.

\section{Data Collection Method}

The study site is located in three villages in Sepauk District, i.e. Sirang Setambang Village, Bedayan Village, and Nanga Libau Village. The reason for the selection of the three villages was due to unlicensed gold mining activities in the area. This study uses primary data from mining communities, non-miners, the head of the district, village apparatuses, NGO, and related government institutions comprising the Office of the Environment, Minerals, and Energy Mining Service, and the Regional Development Planning Board. Secondary data was obtained in the form of documents, records, and official reports.

Data collection methods include observations, in-depth interviews, and documentation. The research instruments used are interview guides, field notes, observation guides, recording devices, photos, and stationery. Researchers conducted interviews with informants who are considered to represent the data needed. Informants from mining communities, non-miners, the head of the district, village apparatuses, NGO, and related government institutions comprising the Office of the Environment, Minerals, and Energy Mining Service, and the Regional Development Planning Board. The first activity conducted is data condensation that is, choosing, simplifying data, and transforming data deemed close to the records in the field. The next step is the presentation of data; in qualitative research, data is usually collected in the form of a short description or narrative text, charts, matrices, relationships between categories, networks, and so forth. In this study, researchers present data in the form of narrative. The third step is the conclusion after the data is saturated, meaning that there has been repetition of information, then the conclusion can be used as the answer to the research problem.

\section{RESULTS AND DISCUSSION}

\section{Social Aspect}

a. Education

Education affects the society in a way that it creates social changes. Social changes as a form of innovation associated with all aspects of human life aiming to improve the welfare of the society. According to Alfonso et al. (2014), educational factors, age and length of stay affect the level of one's income. Education is also one factor that can affect the level of income of a person. The higher one's level of education, the better one's responds to life's problems.

Today, people are aware of the importance of education for their children. Mining activities do not affect education, as based on the results of interviews with the people. The community in the study site agrees that education is now well developed. Public is aware on the importance of school as job competition today is even tighter. Some of these people even have sent their children to college.

\section{b. Health}

Health is a major element for the general welfare; it must be realized in accordance with the ideals of the state. Infrastructure and facilities are urgently needed so as to improve health services. Health services and facilities in Sirang Setambang, Bedayan, and Nanga Libau villages are still inadequate, as evidenced by the secondary data the researchers obtained.

Table 1. Health Facility in Sirang Setambang, Bedayan, and Nanga Libau.

\begin{tabular}{|c|c|c|c|c|}
\hline \multirow[b]{2}{*}{ Village } & \multicolumn{2}{|c|}{ Public Health Centers } & \multirow[b]{2}{*}{$\begin{array}{l}\text { Village } \\
\text { Polyclinic }\end{array}$} & \multirow{2}{*}{$\begin{array}{c}\text { Village } \\
\text { Health } \\
\text { Point }\end{array}$} \\
\hline & $\begin{array}{l}\text { Without } \\
\text { Inpatient }\end{array}$ & Helpers & & \\
\hline Sirang & 0 & 0 & 0 & 1 \\
\hline \multicolumn{5}{|l|}{ Setambang } \\
\hline Bedayan & 0 & 1 & 0 & 0 \\
\hline Nanga Libau & 0 & 0 & 1 & 0 \\
\hline Total & 0 & 1 & 1 & 1 \\
\hline
\end{tabular}

urce: Sepauk in figures 2017

Based on the above table, the health facilities need to be improved, both in terms of numbers and health personnel. The community confirmed 
the data during interviews as they said that the villages need more health personnel, such as doctors, midwives, and nurses. In addition, the village needs an ambulance to facilitate access to better health services.

Miners do not have health insurance, such as BPJS; if an accident happens, those responsible for are the owners of the mining business. When the researchers interviewed miners and nonminers, some confirmed that they still struggled to get BPJS services because the road access was badly damaged. Improving the existing facilities and infrastructure in the village should be the concern of the government.

\section{c. Age and Sex}

Age and sex are important characteristics of the population as it tells us the composition of population; we can see changes that occur from time to time. Based on secondary data, the researchers found that the composition of population by age and sex in Sirang Setambang, Bedayan, and Nanga Libau was similar-the highest earning age was between $18-26$ years old and the second was between $27-40$ years old. The dominant sex in these three villages was male.

Through interviews, miners revealed that children and women were not employed as gold miners. Mining workers on average were quite mature and productive at work. This productive age describes humans are able to strive to meet their needs of life.

\section{d. Race and Religion}

The term religion in the study socioanthropology is a translation of said religion in English, no the same as religion in the language political-administrative government of the Republic Indonesia. In this essay, religion are all called religion in English, including what is called the religion of revelation, the religion of nature, and local religion. "Religion" in the sense political-administrative government of the Republic Indonesia is a recognized official religion by the government, namely Islam, Christianity Protestant, Catholic, Hindu and Buddhist, and in this end-time too including Kongkucu religion (Saifudin 2000: 2). Religion may be regarded as the beliefs and patterns of behavior by which humans try to deal with what they view as important problems that cannot be solved through the application of known technology or techniques of organization. To overcome these limitations, people turn to the manipulation of supernatural beings and powers (Haviland 1996).
A tribe is part of a nation having their own basic characteristics usually related to the origin of a culture, which help to recognize the people, i.e. their physical appearance, language, customs, and art. Human always need a religion as inside they always need an omnipotent to ask for help.

The researchers interviewed the head of Sirang Setambang, Bedayan, and Nanga Libau Village related to the tribes and religions. As expressed by Mr. HT, the Head of Bedayan Village, the majority of the population was Javanese and Sundanese, those once joined the transmigration program, and the majority of the villagers were Muslim. Mr. MT, the Head of Sirang Setambang, and Mr. WG, the Head of Nanga Libau, stated that the majority of the population in their village was Dayak tribe and the religion is mostly Catholic and Protestant religions.

Miners come from different tribes and religions. Mr. EK, a miner, said that gold miners were not only from the surrounding community. People from different tribes and religions worked as gold miners, without thinking much about their social status.

\section{Economic Apsect}

\section{a. Livelihood}

Livelihood is an effort to meet the daily needs by working. Community livelihoods differ from one to another due to the geographical, social and cultural conditions that exist in the local community. The gold mining activities have changed the livelihoods of the communitypreviously as farmers then turned into miners.

Interview with Mr. AT revealed that working as a miner could help to meet the daily needs. Similarly, Mr. EK stated that he had chosen to be a miner, as his previous job had failed to help him to meet the daily needs since the price of rubber was decreased to IDR 6,000 per kilogram. The government needs to help increasing the price of rubber sap to normal so people can return to their previous garden and stop working as a miner.

\section{b. Earnings and Employment Opportunities}

The economy of the community is largely determined by the opportunity to earn income and employment. Opportunities in mining provide a positive impact on the surrounding community as it can improve the economy of the community.

Mr. EK said that mining work could meet his needs of his life although not much too earn. Another informant, ZK, also said the same. Some informants indicate that the existence of gold 
mining provides benefits to a group of people as miners.

\section{Environmental Aspect \\ a. Road Damage}

The road is the basic infrastructure for humans to move from one location to another. At the time of the study, the road conditions in Sepauk were so bad-it was muddy and slippery making transportation difficult.

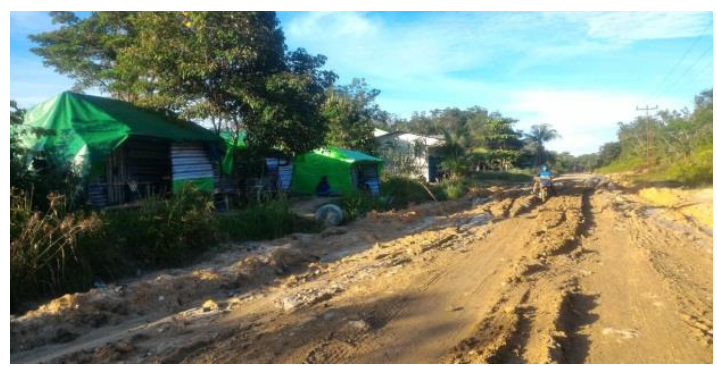

Figure 1. The severely damaged inter-village roads in Sepauk

Before mining, the road had already in such bad condition. Then, it even has turned even worse after the mining activities as some miners work on the part of the road, as stated by Mr. PL.

If the government does nothing as to improve the road condition, the security and comfort of the community is to risk. As a good citizen, the local community actually has to do something to solve the problem while waiting for the government's action.

\section{b. River Pollution}

Mining activities are not only conducted in the mainland but also in the river. According to Kukuh Prasetyo et al. (2017), if mining is done close to the water source, it can degrade the quality of well water and river water. Gold mining in the Sepauk River becomes a concern and problems for the surrounding community. Gold mining using mercury causes river pollution and health problems.

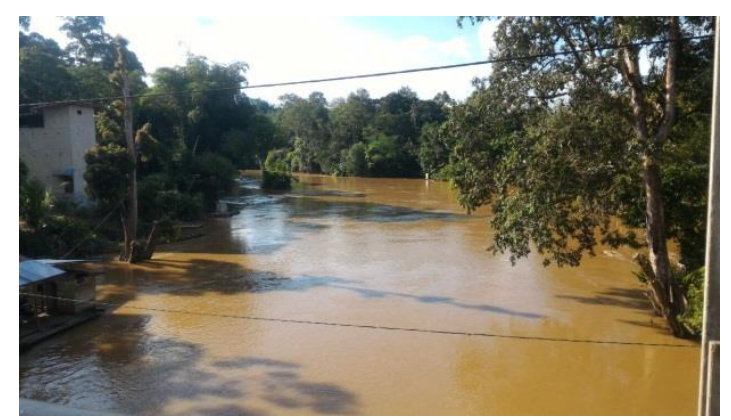

Figure 2. Sepauk river flow - dark brown, dirty, and shallow water.

Local people complain on the pollution of river in Sepauk, as the water no longer can be consumed and causes health problems. Mr. KR's said that long ago, the water in the river was fresh and clean, and there was fish living in it; yet, nowadays, the water only causes health problems.

This river condition has led to many losses. Because river exploitation does not pay attention to the carrying capacity of the environment, the community is being threatened to lose clean water source. People must actually aware of the environmental degradation and change the way they treat the surrounding environment.

\section{c. Deforestation}

The forest cover area is very beneficial for the survival of the earth's surface. Forests also serve to absorb carbon dioxide from the atmosphere through the process of photosynthesis that produces oxygen. The destruction of the forest will result in floods, landslides, and greenhouse effect that cause the temperature to increase. Forest destruction is caused by land conversion in the form of settlement, plantation, mining, agriculture, and others.

The continuous land conversion causes forest destruction, not to exclude, surely, and plantation land used as mining land. The results of interviews with $\mathrm{Mr}$. $\mathrm{CH}$, the Head of Sepauk, showed that before becoming a mine, the area was forests, rubber plantation, and oil palm plantations.

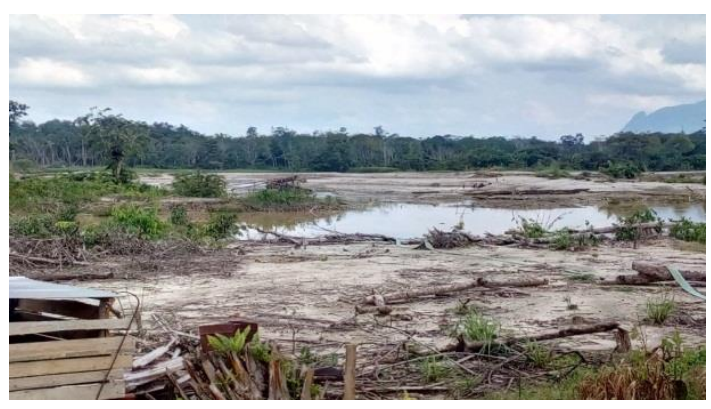

Figure 3. Land damage caused by mining

Mr. HT, the Head of Bedayan Village, also expressed the same answer; he said that some oil plantation had been turned into a mining area and this had led into a conflict between the company and the local community. 


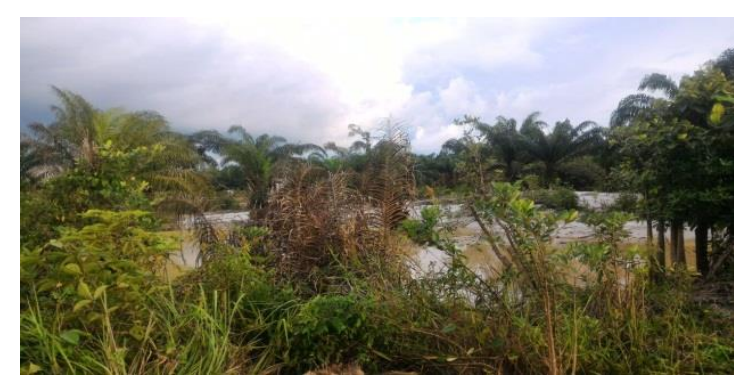

Figure 4. The previously mining areas in an oil plantation

Mr. HT was deeply disappointed about the people who did not care about this problem, especially the miners, as the dispute seems to continue. Land that becomes a mining area without a license will bring a bad impact on the environment.

\section{d. Noise Pollution}

Noise pollution is a disturbance in the environment caused by sounds that result in the inconvenience of the people. The noise caused by the gold mining is so disturbing as mining activities are done not far from the local community settlement. Interview with ZK and Mr. EK revealed that mining location was about 4-5 kilometers from the settlement.

Noise raises anxiety for people who are not far from mining activities based on the explanation of Mr. PL those who work as miners do not care about the sound of the engine that they cause, people around the mining area is quite restless due to the noise made by the machine that felt very disturbing comfort society to worship and rest. This noise can pose a serious threat the local community as well as the surrounding environment especially for the hearing.

\section{Positive Sides of Mining}

\section{a. Improve the Welfare of Miners}

Gold mining activities has help to increase the income of miners because gold price is relatively high, around IDR 488,000 per gram. The statement of Mr. LC, the Head of the Mining Conservation, revealed that a mining company would help to increase the economy of the surrounding community and development in the region. If Sepauk has a mining company, then it will help to increase the development of the region; unfortunately, the mining activities conducted in Sepauk District are unlicensed.

In addition to improving the economy and welfare of the community, these mining activities improve the quality of education in the community, as local people are able to send their children to college.

\section{b. Decrease Unemployment}

Gold mining activities have decreased the number of unemployed. The Head of Sirang Setambang, Mr. MT, revealed that people see mining as an activity offering good amount of money and people are eager to become a miner. In addition to reducing the unemployment rate, it also reduces the crime rate due to better economy level.

\section{Negative Sides of Mining \\ a. Haelth Problems}

Unlicensed gold mining activities generally use mercury to separate gold with other materials. Research according to Ayu F.S, et al (2016) mining seems to have a negative impact on public health conditions, which is indicated by increased ISPA disease in the area around the mine. According to Kukuh Prasetyo, et al (2017) the negative impact of mining is the declining quality of well water and river water. Mining conducted in the Sepauk River has made the river polluted. The community stated that the river water created health problems in the form of itching.

In addition, people no longer want to fish in the river because they know that the fish are contaminated with mercury. Humans can be exposed to mercury directly or indirectly through food chain, such as water biota and fish contaminated with mercury. Mercury poisoning can cause serious health problems in the form of impaired kidney and liver function.

\section{b. Environmental Damage}

Unlicensed gold mining activities in Sepauk District have a negative impact on the surrounding environment. Environmental damage is in the form of road damage, water pollution, forest damage, and noise pollution. The road is crucial for the live of the community in Sepauk, but in reality, the road condition is badly damaged. The researchers interviewed Mr. KS, staff at the Regional Development Planning Board, and he said that infrastructure in a region was very important in development and that taxes received from the mining results could help build road and bridges. Thus, it can be concluded that if the gold mining is licensed, then it will pay taxes and it can help to build more developed infrastructure.

The lack of awareness on the effect of mining toward the environment makes miners neglect the bad impact, such like the use of mercury 
that is very dangerous for both the environment and the people.

Maryani (2007), explained that the impact of damage caused by mining activities can be seen in the environmental damage that occurred. The impact of the damage is the decrease of land quality which is indicated by the decrease of physical, chemical and biological quality of the soil. Land damage caused by mining has led to floods, droughts, and landslides as the carrying capacity of forest and environmental resources are declining. Mine exploitation is done on a large scale without taking into account the severe damage.

Mining activities also cause noise due to the sound of diesel-fueled engines. The community around the mining area is quite disturbed and restless. Unlicensed small-scale gold mining seems to be beneficial to the public, but it costs higher than the profit, in terms of health, environmental damage, and social impact.

\section{c. Land Conflict}

Land conflicts occurring in Sepauk due to mining continue, as an example, the oil company's conflict with the mining community on Land Use Rights. The community, especially miners, said that the area where they work is the plasma recipient land, and the land has not produced any results, so they make the location as a mining area. There are conflicts between the miners and the local people whose land adjacent to the gold mine object the existence of mines, yet inter-community conflicts can be resolved through discussion.

\section{Government Policy on Mining}

Considering that miners may not have considered much about environmental aspects, counseling and guidance must be given, especially by the government. Interview with Mr. S, a Head of Division at Sintang Environmental Protection and Management, revealed that mining activities should have IUP (Mining License), IPR (Traditional Mining License), and IUPK (Special Mining License), or mining business permit as stated in Law Number 4 of 2009 on mineral and coal mining. In relation to the policies set forth in the law, miners must have a mining business license. Regarding the mining permit, Mr. LC said that the procedures and requirements to obtain the mining permit is set by the Government Regulation Number 23 of 2010 on mineral and coal mining business activities.
The government has to be strict related to traditional gold mining. The many unlicensed mining activities are the proof that the government has not completely implemented the existing policies. The law enforcement officers and government are recommended to provide guidance and supervision to mining business as to solve the problem and to reduce the bad impact.

\section{CONCLUSION}

Based on the findings, here are the conclusions of the study. First, the social aspects show that (1) education is sufficiently improved, (2) public finds it difficult in obtaining health insurance and there has been inadequate health infrastructure, (3) productive age is superior to other age, so they have even better potential, and (4) miners come various tribes and religions. Second, the economic aspects show that (1) many people are changing livelihoods as miners, and (2) the income of the community as miners can meet their daily needs. Third, the environmental aspects show that mining has caused road damage, river and water pollution, as well as land damage and noise pollution.

Mining activities have had positive and negative impacts. The positive impacts are in the form of improving people's welfare and reducing unemployment, while the negative impacts are health problems, road damage, river and water pollution, land damage, noise pollution, and land conflicts.

The researchers suggest that the government provides more guidance and supervision for the community, especially the miners. The government provides explanation on procedures to get mining business license. If unlicensed mining continues, then sanctions from the government must be given.

\section{ACKNOWLEDGEMENT}

The authors would like to thank the parties who have helped substantially and financially.

\section{REFERENCE}

[1]. Farlan, Edi, (ed). 2016. Dampak Pertambangan Emas Terhadap Perubahan Sosial Ekonomi Masyarakat di Gampong Mersak Kecamatan Kluet Tengah Kabupaten Aceh Selatan. Dalam jurnal Mahasiswa Pertanian Unsyiah. Vol 1. No.1 Nov 2016. Hal 329-336. 
[2]. FS, Kustiana Ayu, (ed).. 2016. Kondisi Sosial Ekonomi Masyarakat Di Sekitar Pertambangan Nikel DI Kecamatan Bahodopi Kabupaten Morowali. Dalam jurnal Ekonomi. Vol. 1 No.1 April 2016. Hal 135-145.

[3]. H, Alfonsus.,(ed). 2014. "Korelasi Pertambangan Emas Tradisional Terhadap Keadaan Sosial Ekonomi Masyarakat (Studi Kasus di Kabupaten Madina (SUMUT)". Dalam jurnal Balai Penelitian Kehutanan Aek Nauli. Vol 1. No.1 Nov 2014. Hal 1- 17.

[4]. Haviland, B. William A (1996). Cultural Anthropology (8th ed.). Harcourt Brace College Publishers.

[5]. Maryani IS. 2007. Dampak penambangan pasir pada lahan hutan alam terhadap sifat fisik, kimia, dan biologi tanah [skripsi]. Bogor: Fakultas Kehutanan, Institut Pertanian Bogor.

[6]. Miles,M.B, Huberman,A.M, dan Saldana,J. 2014. Qualitative Data Analysis, A Methods Sourcebook, Edition 3. USA: Sage Publications. Terjemahan Tjetjep Rohindi Rohidi, UI-Press.

[7]. Prasetyo Jati, Kukuh, (ed) 2017. Dampak Pertambangan Minyak Tradisional Terhadap Kondisi Sosial Ekonomi dan Lingkungan Hidup. Dalam jurnal GeoEco. Vol.3 No. 1 Januari 2017. Hal.58-67.

[8]. Saifudin, Achmad Fedyani (2000). Agama Dalam Politik Keseragaman. Jakarta:Badan Penelitian dan Pengembangan Agama, Departemen Agama RI.

[9]. T Sugianti, L.G.S Astiti. 2014. Dampak Penambangan Emas Tradisional pada Lingkungan dan Pakan Ternak di Pulau Lombok. Dalam jurnal Sains Peternakan. Vol.12 No. 2 September 2014. Hal 101-106

[10]. Warisman Setio, Fadly, (ed). 2015. Analisis Pengaruh Penambangan Galian C Terhadap Lingkungan Perairan dan Sosial Ekonomi di Desa Kampung Pinang Kecamatan Perhentian Raja Kabupaten Kampar. Dalam jurnal Berkala Perikanan Terubuk. Vol. 43 No.1 Februari 2015.

[11]. Undang-Undang No. 4 Tahun 2009 Tentang Pertambangan Mineral dan Batu-bara.

[12]. Undang-Undang No. 32 Tahun 2009 Tentang Pengelolaan Sumber Daya Alam.

[13]. Undang-Undang No. 23 Tahun 2010 Tentang Pemerintah Daerah.

[14]. http://www.kompas.com diakses tanggal 12 September 2017. 